JURNAL MANAJEMEN \& BISNIS KREATIF

Jurnal IImiah hasil penelitian dan Informasi IPTEKS

Volume. 2 No. 1 Okt 2016 - maret 2017

\section{Susunan Pengelola}

SK. Rektor : 017/SK/A.4/X/2015

Pelindung

Dr. H. Dedi Mulyadi, SE.,MM

Ketua Penyunting

Sari Marliani, SE.,MM

Dewan Penyunting

H. Tarpan Suparman, S.Pd.,M.Pd (UBP

Karawang)

Nelly Martini, SE.,MM

(Unsika)

H. Acim Supriadi, SE.,MM

(UBP Karawang)

Rahmat Hasbullah, SE.,M.Pd

(Unsika)

Abdul Yusuf, SE.,MM

(Unsika)

Yudin Wahyudin, SE.,MM

(STIE YPN)

Jajang Sugiat, SE., MM

(STIE Yasa Anggana)

Yudi Suwandi, SE.,MM

(STIE EKUITAS)

Penyunting Pelaksana

Ajat Sudrajat, SE.,MM

Ina Ratnasari, SE.,MM

Sirkulasi dan Pemasaran

Chandra Zonyfar, S.Kom

Yogi Ginanjar

Alifya Nurzehan

\section{Daftar Isi}

\author{
ANALISIS PENGARUH KUALITAS PELAYANAN \\ TERHADAP KEPUASAN MAHASISWA UNIVERSITAS \\ BUANA PERJUANGAN KARAWANG \\ Wanta \\ $1-21$
}

PENGARUH KESEHATAN DAN KESELAMATAN KERJA (K3) TERHADAP KINERJA KARYAWAN PT. BEKAERT INDONESIA PLANT KARAWANG

Ade Sofyan

$22-45$

PENGARUH GAYA KEPEMIMPINAN TERHADAP MOTIVASI KERJA PEGAWAI SEKOLAH TINGGI ILMU KESEHATAN (STIKES) KHARISMA KARAWANG

Dedi Supriadi, Endang Riswana

$46-81$

ANALISIS PROGRAM PEMASARAN PRODUK UMKM DODOL GARUT

Satim Hamid

$82-112$

\begin{abstract}
ANALISIS KINERJA TENAGA KEPENDIDIKAN TERHADAP KEPUASAN MAHASISWA UNIVERSITAS BUANA PERJUANGAN KARAWANG (Studi Kasus Prodi Manajemen)

Citra Savitri

$113-132$
\end{abstract}

PENGARUH MOTIVASI KERJA, KEPEMIMPINAN DAN BUDAYA ORGANISASI TERHADAP KEPUASAN KERJA KARYAWAN SERTA DAMPAKNYA PADA KINERJA PERUSAHAAN (Studi Kasus pada PT. Concord Indonesia)

Budi Rismayadi, Mumun Maemunah $133-157$

ANALISIS BREAK EVEN SEBAGAI ALAT PERENCANA LABA: KASUS PADA TOKO PUTRA PASTI MANDIRI CIKAMPEK KARAWANG

Santi Pertiwi Hari Sandi

$158-169$

\title{
Alamat :
}

LPPM Universitas Buana Perjuangan

JI. H.S Ronggowaluyo Telukjambe Karawang

Telp/Fax : 0267-8403140

e-mail : jurnal.fbis@ubpkarawang.ac.id

Website : journal.ubpkarawang.ac.id

Jurnal Manajemen \& Bisnis yang diterbitkan oleh LPPM Universitas Buana Perjuangan Karawang terbit dua kali dalam satu tahun (Oktober dan Maret). Jurnal Manajemen \& Bisnis adalah media untuk mempublikasikan karya ilmiah dan pertukaran informasi sebagai upaya peningkatan kualitas akademik bagi dosen, mahasiswa dan masyarakat umum. 